\title{
The toxic effects of phorate on early embryonic stages of sedentary polychaete Hydroides elegans (Haswell, 1883)
}

\author{
S. Vijayaragavan ${ }^{1 *}$ and P. Vivek Raja ${ }^{2}$
}

\begin{abstract}
Background: The toxicity test has been developed to examine the effects of pesticides on fertilization and early development of marine polychaete Hydroides elegans (H. elegans). The pesticides lead to pollution of the ground water, aquatic environments and also marine environment. It directly enters the food chains of the organisms, and it affects the marine ecosystems. The pesticides alter the regular functions of the marine organisms as well as the physiological structure.

Results: The toxic effect of phorate on fertilization, early developmental stages of $H$. elegans, was examined, and it was found that the rate of successful development of embryonic development decreased when the concentration of phorate increased in sea water. The results present here strongly suggest that the mechanism of action of the pesticide probably acts on several intracellular targets based on EC50 values of the present study. It indicates that phorate was most toxic to the early developmental stages of $H$. elegans.

Conclusion: The results indicate that the early development of $\mathrm{H}$. elegans is highly sensitive to phorate. The sedentary polychaete, Hydroides elegans, can be routinely used as a test organism for eco-toxicity bioassays at tropical and subtropical regions.
\end{abstract}

Keywords: Phorate, Hydroides elegans embryo, Fertilization, Blastula

\section{Background}

The urbanization growth endangers the coastal ecosystem and also the ecosystem may be polluted by the discharges from specific point sources like sewage, effluents, and industrial wastes and also from non-point sources like harbors and drainages. Therefore, it is essential that the bioassay techniques should be established to monitor the pollutants that pose a danger or hazard to humans and the biota (Gopalakrishnan, Thilagam, \& Vivek Raja, 2008; Ringwood, 1992).

Phorate is a highly toxic organophosphate pesticide which is used to control the chewing insects, leafhoppers, leafminers, mites, some nematodes, rootworms in pine forests and on root insects, and insects in field crops, including corn, cotton, coffee, and some ornamental and herbaceous plants and bulbs (Fig. 1). It is a relatively stable

\footnotetext{
*Correspondence: vijayaraja100@gmail.com

${ }^{1}$ Indira Gandhi National Open University, Regional Centre, Cochin, Kerala 682017, India

Full list of author information is available at the end of the article
}

clear to yellow liquid in appearance at room temperature, it has been labeled as a highly toxic poison, and it is a restricted use pesticide (RUP) which can be used for specific uses only. It is registered for half use in countries like India, USA, Canada, Australia, and New Zealand which is declared by the Pesticide Action Network (PAN AP, 2001).

It contributes to agricultural waste which moves up to the aquatic environment during the rainy season, and it is transported through the food chain and causes several ailments. It is essential to study the effects of the pesticides by using bio-organism for aquatic environmental management and monitoring (Gopalakrishnan et al., 2008). Most of the pesticides affect the embryo, causing teratogenic effects by directly or indirectly affecting the cellular physiology (Calevro, Campani, Rangghianti, Bucci, \& Mancino, 1998). Many cases of surface water contamination with pesticides were noticed and reported (Halder, Raha, Bhattacharya, Choudhur, \& Adityachoudhury, 1989).

Bioassays allow the detection of the effects by measuring the biologic response of marine organisms, 


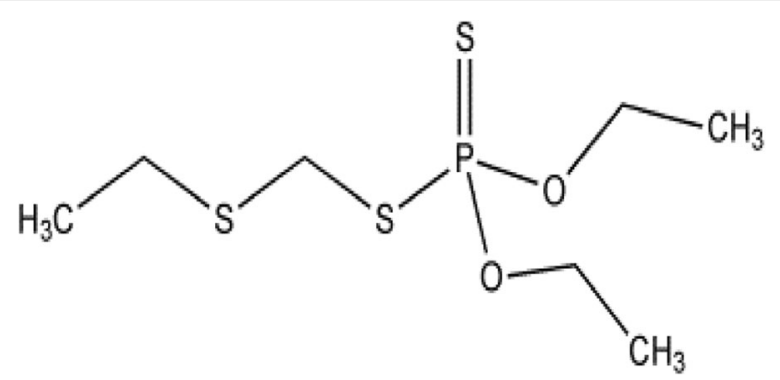

Fig. 1 Molecular structure of phorate

particularly in their early life stages (His, Beiras, \& Seaman, 1999). The test species must be sensitive enough to respond to low levels of contaminants and must be available for use either from laboratory cultures or from field collection throughout the year; accordingly, biologic tests are to be ecologically relevant and easily available to species for experimentation (Gopalakrishnan et al., 2008; Richardson \& Martin, 1994). Although toxicity tests conducted in the field are desirable and analyzing the developmental stages are easier to perform, only the laboratory conditions provide accurate results which are highly useful.

The early developmental stages of marine invertebrates have repeatedly been found to be more sensitive to environmental pollutants than their adult counterparts (Connor, 1972; Rand, Wells, \& McCarty, 1995). Hence, they are subjected to the toxicity tests in most of the cases. A number of early life-stage toxicity testing protocols have been developed are effectively applied for seawater toxicity using marine species of their early embryo; for example, bioassays using embryos of bivalve species (Mytilus edulis, Crossostrea virginice, and C. gigas) and gametes of echinoderm species (Strongylocentrotus purpuratus, S. tranciscanus, and Arabica punctuata) have been developed (ASTM, 1995; Dinnel, Link, \& Stober, 1987).
Some of the field collected organisms only produce viable gametes for a certain period of the year, which limits their use in routine toxicity testing. Furthermore, it is noted that sea urchins require 5 to $10 \mathrm{~min}$ for fertilization, $1 \mathrm{~h}$ for first cleavage, $24 \mathrm{~h}$ for blastula and gastrula, and $48 \mathrm{~h}$ for trochophore larva (Qiu, Tremblay, \& Bourget, 2002). In contrast $H$. elegens requires 2 to $3 \mathrm{~min}$ for fertilization, $30 \mathrm{~min}$ for first cleavage, and approximately $12 \mathrm{~h}$ for distinguishable trochophore larva Vijayaragavan, 2009). Therefore, the advantages of developing bioassays using $H$. elegans embryos are more clear and accurate.

H. elegans (Haswell, 1883), a sedentary, tubicolous serpulid polychaete, is common in all temperate regions and produces viable gametes throughout the year (Raja, 1999; Sellappan, 2000; Gopalakrishnan, 2002) (Fig. 2). The organism is widespread forming dense layers within the collection zone. It can be easily collected and amenable to laboratory holding and can be readily induced to release gametes and potential for use in routine laboratory toxicity tests (Gopalakrishnan \& Raja, 2002; Raja, 1999; Vijayaragavan, 2009). Therefore, the aim of the present study was to determine the toxic effects of phorate on early embryonic stages of $H$. elegans.

\section{Materials and methods}

\section{Collection of organism}

H. elegans were collected from the hulls of boats, which were in fishing operation for more than 3 months, berthed at Royapuram, Fish Landing Center, Chennai, India (Lat. $13^{\circ} 06^{\prime} \mathrm{N}$ and Long. $80^{\circ} 18^{\prime} \mathrm{E}$ ). Other sedentary animals like Lepas, Barnacles, Neries, Mytilus, Ascidians, Algae, and few crustacean arthropods were also seen which were carefully removed from the collection before placing $H$. elegans in the collection chambers containing freshly collected seawater. These specimens were transported to the laboratory within an hour after

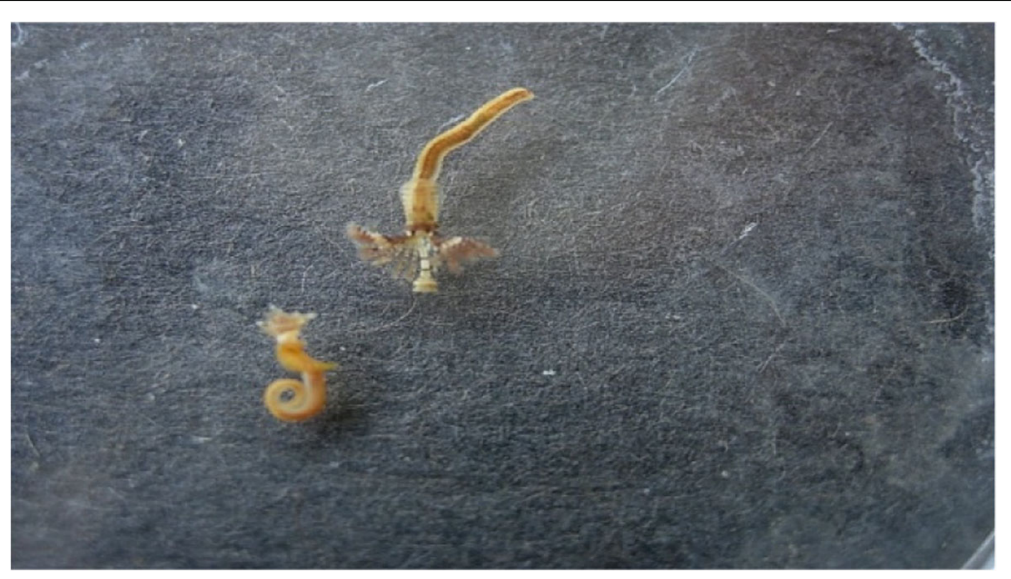

Fig. 2 H. elegans without a tube 
collection, reared in rectangular glass tanks, and acclimatized to laboratory conditions for 3 days. Tank holding conditions were 7-9 $\mathrm{mg} / \mathrm{L}$ dissolved oxygen, salinity $(34 \pm 1 \mathrm{ppt})$, temperature $\left(28 \pm 10{ }^{\circ} \mathrm{C}\right)$, and $\mathrm{pH}(8.1 \pm 0.1)$. Illumination was provided in a light to dark cycle of 14:10 h. The polychaetes Hydroides elegans were kept completely immersed in seawater until the test was initiated.

\section{Experiment procedure}

Tests were conducted in 100-ml glass beakers containing $50 \mathrm{ml}$ of the filtered sea water. The sex of the polychaete was distinguishable by the orange color of the female abdomen and creamy white of the male abdomen. The eggs were visible to the naked eye. Release of gametes began almost immediately and was allowed to continue for $10 \mathrm{~min}$, after which the animals were removed. Gamete release after removal from the calcarious tube is a stress response in polychaete (Strathmann, 1987). Five to10 male and 10 to 15 female individuals were used per toxicity test. Two hundred eggs were used for each concentration, and six replicates per treatment were analyzed.

\section{Selection of eggs}

After complete spawning, the worms were removed from the watch glasses. The watch glass with eggs and seawater was slightly swirled or rotated in such a way that the bigger and heavier mature eggs settled in the center and the lighter and smaller eggs remained at the periphery of the watch glass. Such smaller eggs along with some seawater were decanted out. This process was repeated five times. By this method, the eggs were also washed well. Only bigger, heavier, and healthier eggs were selected for the experiment, and unwanted debris was removed. Eggs were used for the experiment within $15 \mathrm{~min}$ of release.

\section{Maintenance of sperm}

After spawning, the worms were removed from the watch glasses. The sperm were released and were kept in $10 \mathrm{ml}$ of seawater till the beginning of the experiment. The sperm were used for the experiments within 5-10 min after release.

\section{Experiment}

About 200 eggs were introduced into each test chamber containing fresh sea water by Pasteur pipette. Then $0.5 \mathrm{ml}$ of sperm suspension was added to each test chamber and the stopwatch was switched on. After $3 \mathrm{~min}$, about $20 \mathrm{ml}$ of solution with about 50 eggs from each container was transferred to separate watch glasses and was observed under a microscope at $\times 150$ magnification. The percentage of successful development of each developmental stages such as elevation of the fertilization membrane (FM) stage and other early embryonic stages namely 2-cell stage, 3-cell stage, 4-cell stage, 8-cell stage, 16-cell stage, 32-cell stage, 64-cell stage, blastula stage, blastula rotation stage, and larval release stage was observed. The experiment was repeated six times and the values were recorded $(n=6)$. To confirm the percentage of successful development, about 100 to 200 developing eggs at different stages were fixed in $10 \%$ neutral buffered formalin prepared in seawater and were counted on the same day. Abnormal cells were also noted at all concentrations and in each developmental stage. A Nikon Photostat research microscope was used to record photomicrographs. The size of the cell at the developmental stage was observed by using a compound microscope. The percentage of successful development was calculated.

\section{Statistical analysis}

To test the effects of various concentrations of phorate, a one-way analysis of variance (ANOVA) was performed for the experiments. All of the abovementioned statistical analyses were carried out by using the Software Statistical Package for Social Science (SPSS, 1999).

\section{Pesticide solution}

Phorate $(10 \% w / w)$, brand name Kemfort, was obtained from Keminol Enterprises, SIDCO north phase Ambattur, Chennai, India. Eight hundred milligrams of phorate $(10 \% \mathrm{w} / \mathrm{w})$ was dissolved in $2000 \mathrm{ml}$ of filtered seawater in a volumetric flask to prepare $40 \mathrm{ppm}$ of phorate in seawater. This stock solution was stored in an amber-colored bottle. From the stock solution, the following concentrations of phorate in seawater ( 0.05 to $40 \mathrm{ppm})$ were prepared and the stock solution was used for the experiment.

In each experiment, filtered seawater was used as control solution. All glass ware were acid washed and rinsed in distilled water. Before the experiment, the experimental concentrations were chosen on the basis of preliminary trials. The concentrations $0.05,0.1,0.25,0.5,1,2,5$, $10,20,30$, and $40 \mathrm{ppm}$ of phorate in sea water were used for toxicity study by using the embryo of $H$. elegans. Physicochemical conditions of the experimenters were $28 \pm 1{ }^{\circ} \mathrm{C}$ temperature; $34 \pm 0.5$ ppt salinity, $6 \pm 0.3 \mathrm{mg} / \mathrm{L}$ $\mathrm{O}_{2}$, and $8.1 \pm 0.1 \mathrm{pH}$ were maintained.

\section{Results}

\section{Normal fertilization and early developmental stages}

After the fertilization, the fertilization membrane was initiated 3 to $5 \mathrm{~min}$. The first cleavage was meridional and the completion of first cleavage acquired at $30 \mathrm{~min}$ after fertilization. The percentage of successful development of the FM stage was $97.63 \pm 1.07$, and it is decreased gradually to $74.00 \pm 1.00$ at the normal larval release stage (Fig. 3). The cumulative time of the FM stage was $5.20 \pm 0.28 \mathrm{~min}$, and the times were steadily increased to $300.50 \pm 2.12 \mathrm{~min}$ 


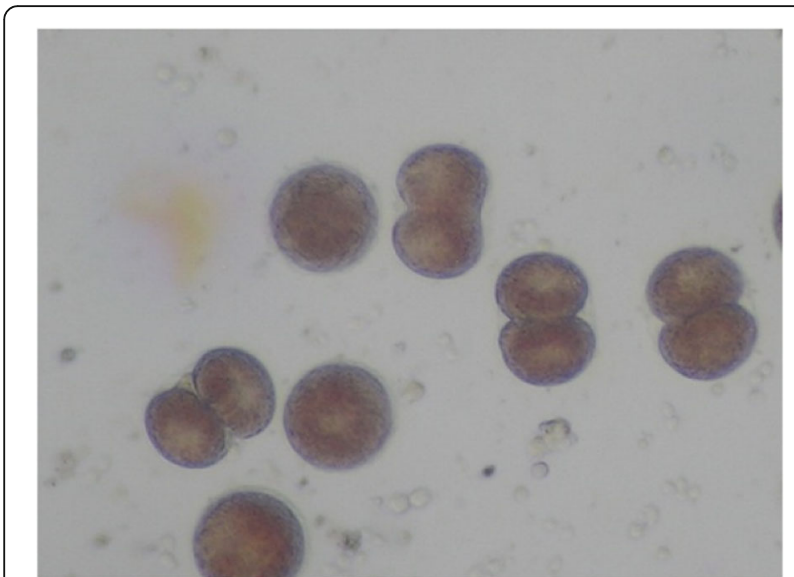

Fig. 3 FM stage and two-cell stage

at the larval release stage. The larval release stage was acquired at $5 \mathrm{~h}$ after the fertilization in the normal development without the phorate in sea water.

\section{Toxic effect of phorate on the early developmental stages} Fertilization membrane (FM) stage to 8-cell stage

The percentage of successful development of the FM stage was $94.05 \pm 2.07$ at $0.05 \mathrm{ppm}$ of phorate in sea water. The cumulative time of the FM stage was $7.50 \pm 0.70 \mathrm{~min}$ at $0.05 \mathrm{ppm}$ of phorate, and the percentage of successful development of the 8-cell stage was $78.33 \pm 5.13$ at $0.05 \mathrm{pm}$ of phorate; it was steadily decreased to $11.67 \pm 4.93$ at $20 \mathrm{ppm}$, and beyond $20 \mathrm{ppm}$ phorate in sea water, there was no development observed.

\section{6-cell stage to 64-cell stage}

The percentage of successful development of the 16-cell stage was $75.67 \pm 5.68$ at $0.05 \mathrm{ppm}$ of phorate in sea water. The cumulative time of the 16-cell stage was $86.00 \pm 5.65 \mathrm{~min}$ at $0.05 \mathrm{ppm}$ of phorate, and the percentage of successful development of the 64-cell stage was $49.00 \pm 7.93$ at $1 \mathrm{ppm}$; it was decreased to $20.33 \pm 13.2$ at $10 \mathrm{ppm}$ phorate in sea water, and beyond $10 \mathrm{ppm}$, there was no development of the 64-cell stage. The cumulative time of the 64-cell stage was $172.00 \pm 4.42 \mathrm{~min}$ at $1 \mathrm{ppm}$ and it was increased to $226.00 \pm 7.81 \mathrm{~min}$ at $10 \mathrm{ppm}$ of phorate in sea water.

\section{Blastula stage to release stage}

The percentage of successful development of the blastula stage was $68.00 \pm 7.00$ at $0.05 \mathrm{ppm}$ of phorate in sea water and the cumulative time of the blastula stage was $141 \pm 8.48 \mathrm{~min}$ at $0.05 \mathrm{ppm}$ of phorate in seawater (Fig. 4). The percentage of successful development of the blastula stage was $47.33 \pm 8.3$ at $1 \mathrm{ppm}$; it was decreased to $33.33 \pm 10.6$ at $5 \mathrm{ppm}$ phorate in sea water, and beyond $5 \mathrm{ppm}$, there was no development observed.

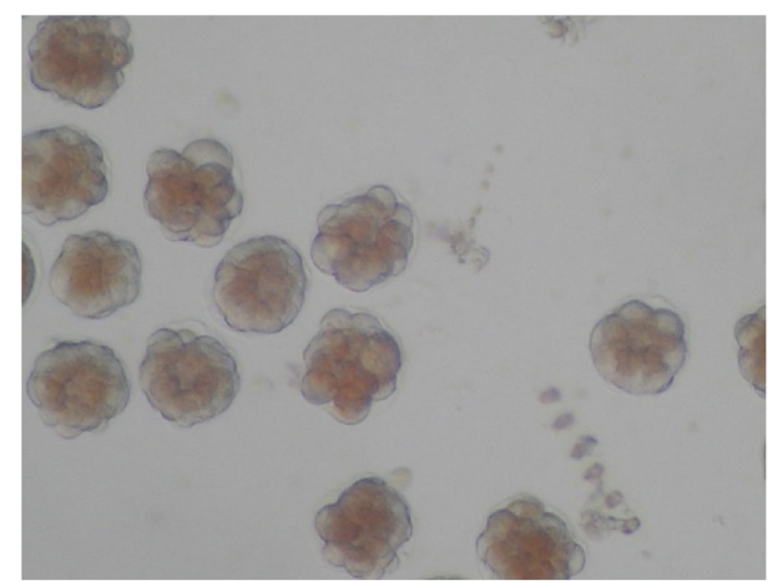

Fig. 4 Blastula stage

The present study observed that the blastula rotation stage was observed up to $5 \mathrm{ppm}$ and above $5 \mathrm{ppm}$ there was no rotation. The percentage of successful development of the release stage was $60.00 \pm 7.21$ at $0.05 \mathrm{ppm}$ of phorate; it was decreased to $21.67 \pm 14.3$ at $5 \mathrm{ppm}$ phorate in sea water, and beyond $5 \mathrm{ppm}$, there was no release stage observed. The cumulative time of release stage was $309.00 \pm 11.3 \mathrm{~min}$ at $0.05 \mathrm{ppm}$ of phorate in sea water, and it is increased to $421.50 \pm 6.58 \mathrm{~min}$ at $5 \mathrm{ppm}$.

Polychaetes are the most widely used groups of marine macro invertebrates in toxicological testing, and their case in collection undoubtedly played an important role in their selection as test animals (Gopalakrishnan et al., 2008; Reish \& Gerlinger, 1997). Polychaetes are ecologically important marine organisms, making up from 30 to $80 \%$ of the total numbers of benthic fauna regardless of the ocean depth (Hutchings, 1998).

The results present here strongly suggest that the mechanism of action of the pesticide probably acts on several intracellular targets based on EC50 values of the present study. It indicates that phorate was most toxic to the early developmental stages of $H$. elegans.

Sensitivity of pollution depends on the type of organism and the stage of development used. The results from the present study indicate that the embryos and larvae of $H$. elegans were more sensitive for phorate in sea water.

The effective concentration value $\left(\mathrm{EC}_{50}\right)$ referred to sensitivity towards the embryonic stages while exposed to different concentrations of phorate in sea water. The result indicates that the $\mathrm{FM}$ stage $\mathrm{EC}_{50}$ value was $5.6146 \mathrm{ppm}$ which is the least sensitive stage of phorate in sea water and highest sensitive stage value was $0.2782 \mathrm{ppm}$ at the larval release stage (Table 1).

\section{Discussion}

The results revealed that the stage $\mathrm{EC}_{50}$ value of phorate decreased steadily from $5.6146 \mathrm{ppm}$ in the FM stage to 
Table 1 Comparison of stage $\mathrm{EC}_{50}$ values of phorate for different embryonic stages of $\mathrm{H}$. elegans (temp. $28 \pm 0.2^{\circ} \mathrm{C}$, salinity $34 \pm 0.1 \% 00, \mathrm{pH} 8.1 \pm 0.1$ ) (stage $\mathrm{EC}_{50}$ values are expressed in ppm)

\begin{tabular}{llll}
\hline Developmental stages & $\begin{array}{l}E C_{50} \text { values } \\
\text { of phorate }\end{array}$ & $\begin{array}{l}\text { Developmental } \\
\text { stages }\end{array}$ & $\begin{array}{l}E C_{50} \text { values } \\
\text { of phorate }\end{array}$ \\
\hline FM stage & 5.6146 & 32-cell stage & 0.9501 \\
2-cell stage & 3.9352 & $\begin{array}{l}\text { 64-cell stage } \\
\text { 3-cell stage }\end{array}$ & 0.7143 \\
4-cell stage & 3.8298 & $\begin{array}{l}\text { Blastula stage } \\
\text { B-cell stage }\end{array}$ & 0.6164 \\
16-cell stage & 1.8989 & $\begin{array}{l}\text { Blastula start } \\
\text { rotation stage }\end{array}$ & 0.3891 \\
& 1.3889 & $\begin{array}{l}\text { Blastula stop } \\
\text { rotation stage }\end{array}$ & 0.3891 \\
& 0.9528 & Release stage & 0.2782 \\
\hline
\end{tabular}

$0.2782 \mathrm{ppm}$ in the release stage. It is indicated that the release stage (hatching) is more sensitive to phorate than the earlier stages, but actually it may be due to longer exposure of embryo to the pesticides in the seawater and also later developmental stages. This suggests that the impact of toxicity may be additive as the development progresses through various stages and thus the later stages are exposed for longer duration in the test solution.

Perusal of the results of the present study on the effects of phorate on fertilization in $H$. elegans reveals that the success rate of fertilization decreases as the concentration of phorate increases in seawater. Successful fertilization was evidenced by the elevation of fertilization membrane. Successful fertilization was 97:63 $\pm 1.07 \%$ successful in control sea water, and it gradually decreased to $15.33 \pm 6.65$ at $30 \mathrm{ppm}$. There was no fertilization at $40 \mathrm{ppm}$. A similar trend was reported in the same species on effect of Monocrtophos, D.D.T., Chlorfyrifos, Endosulfan (Sellappan, 2000). Heavy metals (Gopalakrishnan \& Raja, 2002) and petroleum oils (Sellappan, 2000; Vignesh, 2002) were also reported on the same species.

The percentage of successful development of $H$. elegans declined as the developmental stages progressed in any given concentration of phorate in seawater. In the same way, abnormal development of the various developmental stages increased when the concentration of phorate increased in seawater (Fig. 5). In higher

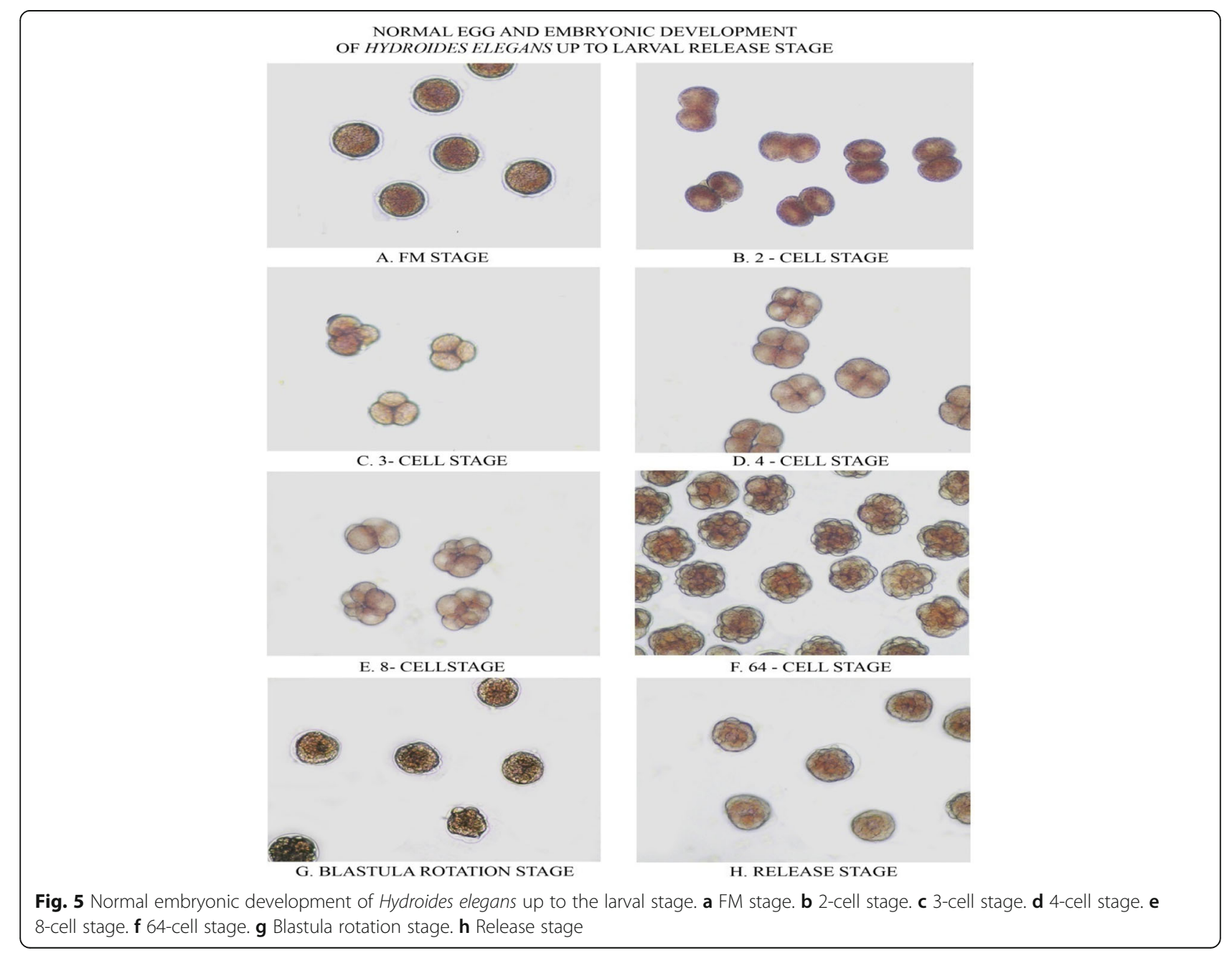




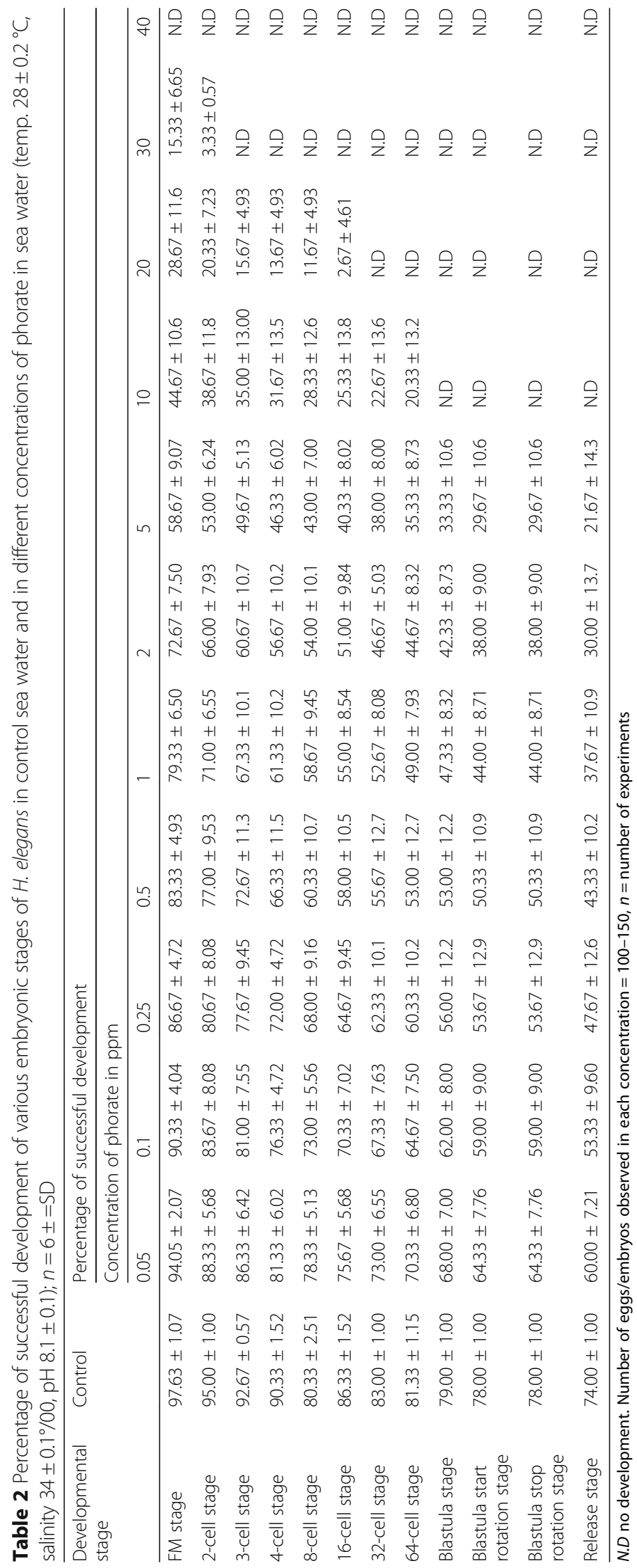




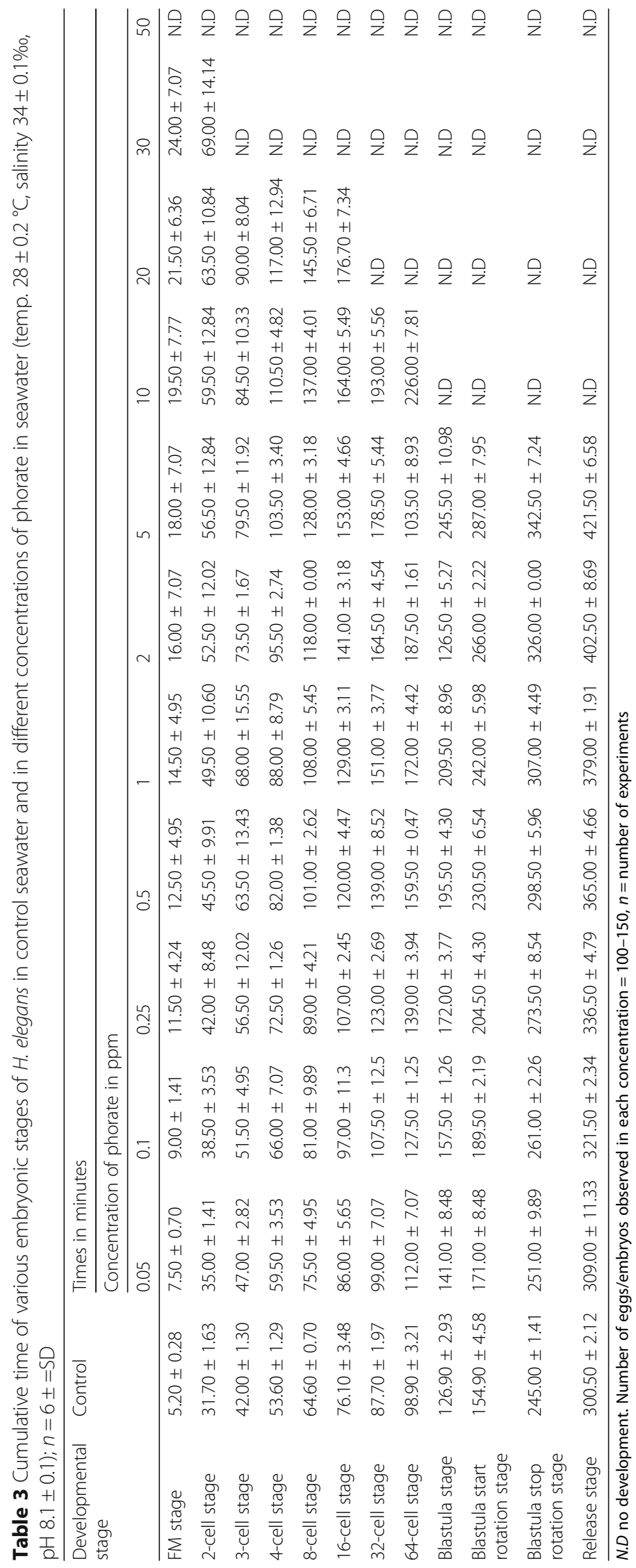


concentrations, the development was arrested due to the effect of phorate.

In the present study, the cumulative time at different developmental stages of $H$. elegans from the FM stage to the release stage (hatching) showed a gradual increase in time as the concentration of phorate increased in seawater in all the stages. It reveals that the rate of development decreases with increase in concentration of phorate in seawater. A similar trend was observed by Thilagam et al. (2008).

The individual stage time of different development stages of $H$. elegans increased except the blastula rotation stage (Tables 2 and 3). At the blastula rotation stage, phorate affects the ciliary activity of the embryo. Hence, the rotation time decreases gradually when the concentration of phorate increases in the seawater. This decrease in rotation time cannot be considered as an increase in the rate of development. In this stage (blastula stop rotation stage), decrease in rotation time may be considered as decrease in rate of development. Hence, it may be inferred that in blastula stop rotation stage also the rate of development decreases with increase in the concentration of phorate; the similar trend was observed for various heavy metals and pesticides (Sellappan, 2000; Raja and Sellappan 1992; Thilagam et al., 2008). It has been already reported that the ciliary activity is essential for successful hatching in sea urchin (Okazaki, 1975). Any reduction in the ciliary activity affects the rate of successful hatching in $H$. elegans (Gopalakrishnan, 2002).

Many insecticides affect the nervous system at different target sites. The insecticides interfere with the membrane transport or sodium, potassium, calcium, or chlorine ions inhibit selective enzyme activities (Ecobichon, 1991). In sea urchins, a specific enzyme called "hatching enzyme" is produced before hatching of blastula (Okazaki, 1975).

In $H$. elegans, the reduction in the rotation time in the presence of phorate suggests that the metabolic activity is reduced, as the quantity of the hatching enzyme released in the final stages of embryonic development may decrease or the secretion process is slowed down. The decrease/delay in the production of hatching enzyme may be ascertained from the increased hatching time of $H$. elegans in the presence of phorate in sea water. The hatching time (release time) of $H$. elegans was $300.50 \pm 2.12 \mathrm{~min}$, and it gradually increases to $421.50 \pm 6.58 \mathrm{~min}$ at $5 \mathrm{ppm}$ of phorate.

From the results, it may be inferred that the rate of production of the hatching enzyme decreased in the presence of phorate, as there was some delay in hatching up to $2 \mathrm{ppm}$ of phorate, and the production of enzyme was reduced below the critical level or completely arrested at $10 \mathrm{ppm}$ and above.

\section{Conclusion}

The experimental data revealed that the toxicity of phorate on early embryonic stages of $H$. elegans is more sensitive, and it leads to abnormalities of embryos. Hence, the development stages have been arrested in high concentrations of phorate in sea water. It was observed that the toxicity particles have induced the abnormalities in the early embryo developments of $H$. elegans. Furthermore, the availability of $H$. elegans throughout the year was favorable and suitable for laboratory toxicity tests. Phorate is an insecticide which has more toxic effects on the early embryonic stages of $H$. elegans and also leads to environment pollution.

\section{Acknowledgements}

We declare that we have no acknowledgements.

Funding

We declare that there are no funding sources.

Availability of data and materials

Please contact author for data request.

Authors' contributions

SV designed the works, performed the experiments, and drafted the manuscript. PVR guided the work. Both authors read and approved the final manuscript.

Ethics approval and consent to participate

We declare that we do not need ethics approval regarding our work on the marine polychaete worm $\mathrm{H}$. elegans.

\section{Consent for publication}

The authors declare that the consent has been given for publication of the manuscripts.

\section{Competing interests}

The authors declare that they have no competing interests.

\section{Publisher's Note}

Springer Nature remains neutral with regard to jurisdictional claims in published maps and institutional affiliations.

\section{Author details}

${ }^{1}$ Indira Gandhi National Open University, Regional Centre, Cochin, Kerala 682017, India. '2Department of Zoology, Presidency College, Chennai, Tamil Nadu 600005, India.

Received: 5 July 2018 Accepted: 21 October 2018

Published online: 06 November 2018

\section{References}

ASTM (American Society for Testing and Materials) (1995). Standard guide for conducting acute, chronic and life cycle aquatic toxicity tests with polychaetous annelids, (pp. 1009-1028). Philadelphia: ASTM.

Calevro, F., Campani, S., Rangghianti, M., Bucci, S., \& Mancino, G. (1998). Test of toxicity and teratogenicity in biphasic vertebrates treated with heavy metals $\left(\mathrm{Cr}^{3+}, \mathrm{Al}^{3+}, \mathrm{Cd}^{2+}\right)$. Chemosphere, 37, 3011-3017.

Connor, P. M. (1972). Acute toxicity of heavy metals to some marine larvae. Marine Pollution Bulletin, 3, 190-192.

Dinnel, P. A., Link, J. M., \& Stober, O. J. (1987). Improved methodology for a seaurchin sperm cell bioassay for marine waters. Archives of Environmental Contamination and Toxicology, 16, 23-32.

Ecobichon, D. J. (1991). Toxic effects of pesticides. In M. O. Amdur et al. (Eds.), Casarett and Doull's toxicology - The basic science of poisons, (4th ed., pp. 565-622). New York: McGraw-Hills, Inc..

Gopalakrishnan, S., \& Raja, P. V. (2002). The effects of copper on sperm and eggs of Hydroides elegans. In proc. XX. National Symp. Reproductive Biol. Comp. Endocrinol, (pp. 83-84). Tiruchirappallai: Bharathidasan University.

Gopalakrishnan, S., Thilagam, H., \& Vivek Raja, P. (2008). Comparison of heavy metal toxicity in life stages (spermiotoxicity, egg toxicity, embryotoxicity and larval toxicity) of Hydroides elegans. Chemosphere, 71, 515-528. 
Halder, P., Raha, P., Bhattacharya, A., Choudhur, A.k., \& Adityachoudhury, N. (1989). Studies on the residues of D.D.T and Endosulfan occurring in Ganga water. Indian Journal of Environmental Health, 31, 156-161.

Haswell (1883). Hydroides elegans worms editorial board. World Register of Marine Species, 131002

His, E., Beiras, R. and Seaman, M.N.L. (1999). The assessment of marine pollution bioassays with bivalve embryos and larvae. In: South ward, AJ., Tyler, P.A., Young, C.M. (Eds)., Advances in Marine Biology Academic press, Sandiego, pp. 1-178.

Hutchings, P. (1998). Biodiversity and functioning of polychaetes in benthic sediments. Biodiversity and Conservation, 7, 113.

Okazaki, K. (1975). Spicule formation by isolated micromeres of the sea urchin embryo. American Zoologist, 15, 567-581.

PAN AP (2001). Pesticide destroy our world, (pp. 1-53). Asia and the pacific Publication December. www.panap.net

Qiu, J. W. Tremblay, R., \& Bourget, E. (2002). Ontogenetic changes in hyposaline tolerance in the mussels Mytilus edulis and M. trossulus: implications for distribution. Marine Ecology Progress Series, 228, 143-152.

Raja, P. V. (1999). Hydroides elegans (Haswell) an ideal organism to study pollution in seawater. XXVI International ethological conference Bangalore. Advance Ethology, 34, 225

Raja, P. V., \& Sellappan, M. (1992). Fertilization and early development of a sedentary polychaete Hydroides elegans from Madras coast. In 11th National Symposium on life sciences Madras, Abstract, (p. 58).

Rand, G.M., Wells, P.G. and McCarty LS (1995). Introduction to aquatic toxicology. Rand, G.M. Fundamentals of aquatic toxicology, effects, environmental fate and risk assessment. Springer, Berlin, 3-70.

Reish, D. J., \& Gerlinger, T. V. (1997). A review of the toxicological studies with polycheatus annelids. Bulletin of Marine Science, 60, 584-607.

Richardson, B. J., \& Martin, M. (1994). Marine and estuarine toxicity testing: A way to go? Additional sittings from northern and southern hemisphere perspectives. Marine Pollution Bulletin, 28, 138-142.

Ringwood, H. A. (1992). Comparative sensitivity of gametes and early developmental stages of a sea urchin species (Echinometra matnei) and a bivalve species (Isognomon californicum) during metal exposures. Archives of Environmental Contamination and Toxicology, 22, 265-288.

Sellappan, M. (2000). Effects of oil and pesticides on fertilization and early developmental stages of sedentary polychaete, H. elegans (Haswell 1883) Doctoral thesis, (pp. 1-150). University of Madras.

SPSS (1999). Statistical package for social sciences. NewYork: SPSS Inc.

Strathmann, M. (1987). Reproduction and development of marine invertebrates of the northern pacific coast: Data for the study of eggs, embryos and larvae, ( $p$. 670). Seattle: University of Washington Press.

Thilagam, H., Gopalakrishnan, S., \& Vijayavel, K. (2008). Effluent toxicity test using developmental stages of the marine polychaete. Contamination and Toxicology, 54(4), 674-83

Vignesh, V. (2002). Effects of petroleum oils on fertilization of marine polychaete. In Intel science Talent Discovery Fair, National Fair, II.T.T. Research project \# DEL. EVI - 045, (pp. 1-15).

Vijayaragavan, S. (2009). The effect of phorate and carbendazim on spawning, fertilization and early developmental stages of sedentary polychaetes Hydroides elegans (Haswell 1883) Doctoral Thesis, (pp. 1-180). University of Madras.

\section{Submit your manuscript to a SpringerOpen ${ }^{\circ}$ journal and benefit from:}

- Convenient online submission

- Rigorous peer review

- Open access: articles freely available online

- High visibility within the field

- Retaining the copyright to your article

Submit your next manuscript at $\boldsymbol{\nabla}$ springeropen.com 